\title{
Correction to: Effects of Physician Experience, Specialty Training, and Self-referral on Inappropriate Diagnostic Imaging
}

Gary J. Young, J.D., Ph.D', Stephen Flaherty, M.B.A., Ph.D², E. David Zepeda, Ph.D³, Koenraad J. Mortele, M.D. ${ }^{4}$, and John L. Griffith, Ph.D ${ }^{7}$

${ }^{1}$ Northeastern University, Boston, MA, USA; ${ }^{2}$ Harvard Pilgrim Health Care, Wellesley, MA, USA; ${ }^{3}$ School of Public Health, Boston University, Boston, MA, USA; ${ }^{4}$ Beth Israel Deaconess Medical Center, Harvard Medical School, Boston, MA, USA.

$\mathrm{J}$ Gen Intern Med

DOI: $10.1007 / \mathrm{s} 11606-020-05761-\mathrm{x}$

(c) Society of General Internal Medicine 2020

C ORRECTION TO: J GEN INTERN MED

https://doi.org/10.1007/s11606-019-05621-3

There were some errors in the variables in this paper. The original article has been corrected.

The online version of the original article can be found at https://doi.org/10. 1007/s11606-019-05621-3 